\title{
"Sprachpraxis" and Mass Customization
}

\author{
Conor Geiselbrechtinger (Düsseldorf)
}

\begin{abstract}
The language component of a degree in English in Germany, or "Sprachpraxis" as it is known in some universities, has in recent years faced a number challenges. Not only are German universities adapting to the B.A./M.A. system but also the very nature of teaching English globally, primarily teaching English as a Lingua Franca (E.L.F.), has had profound effects. This paper aims to explore the most salient questions that have arisen with regard to issues such the role of the native speaker (NS), identity, culture and language. Further, the question will be discussed as to how "mass customization" may be directly applied to the German university. While the introduction of such a system is not without its problems, it could be beneficial to the student, the practitioner and the university as a whole.
\end{abstract}

$" . .$. it is never excessive, when writing in English about English Studies, to remind ourselves of the fundamental asymmetry between the study of English in the UK and Ireland and its study in Continental Europe, where it is a foreign language, not a domestic, discipline. Indeed, it can be misleading in a number of ways to consider 'English' as exactly the same discipline in the UK, in Ireland, and in nonAnglophone Europe - and yet it cannot be considered in each case a discipline apart from that practised in the other." (Kayman et al. 2006: 2f.)

\section{$1 \quad$ Introduction}

The above quote demonstrates that when comparing the degree programmes in English Studies across Europe, on a very basic curricular level, it can be seen that a degree in English Studies in Germany will contain a language component that is absent in the U.K. and Ireland. Unlike established disciplines such as Literary Studies, Linguistics and Medieval Studies, the language component has never gained much attention, in spite of the fact that the very nature of teaching English has been the source of a global debate. Indeed, there is an argument to suggest that the teaching in German universities has hardly changed in the past decades and the status quo rarely challenged. However, it is highly debatable whether the present form of teaching is still tenable, as a number of global, local and institutional factors have had a huge influence on the teaching of English generally, which in turn apply directly to teaching English at German universities. This paper will give an overview of the factors involved and the questions that have arisen. It will also examine strategies that may be employed and how mass customization may be a solution for the future.

\section{Sprachpraxis}

In many universities across Germany the language component is called Sprachpraxis and Lektoren, who teach Sprachpraxis, have traditionally operated in their capacity as the "Native-Speaker" (NS) in English Departments in Germany. Their primary role is to teach "authentic" grammatically and idiomatically correct written and spoken NS English in gram- 
mar and translation courses for example, while at the same time imparting "authentic" cultural knowledge from the Anglophone world. The courses with a cultural focus have traditionally been called Landeskunde. As the word Praxis suggests, the teaching is to develop the practical oral, written and intercultural skills of the students. However, teaching of this nature is based on a number of tenuous assumptions. Firstly, it presupposes that both a uniform definition of the NS and clear goals in teaching exist and that the NS is most qualified to teach. Indeed, in the past, the tenure of four or five years of a Lektor was based on the notion of "importing" fresh blood into the departments of English. It also presupposes that this form of teaching is exactly what students are interested in and desire. In fact, Erling's (2004: 209) research at the FU Berlin shows that students study English for different reasons and have quite divergent attitudes. Although a majority of students still see themselves in what Erling terms the ProBritish and U.S.-friendly clusters, 34\% saw themselves in the Lingua-Franca cluster, in so far as a course of studies in English is seen as a development in their identity as opposed to having any real interest in the Anglophone world and thus see little sense in trying to imitate or emulate the traditional NS.

\section{Teaching English as a Lingua Franca}

To gain an insight into the questions relating to Sprachpraxis, it must be placed within the context of global developments especially in the last twenty years. While much research has concentrated on varieties of English, simultaneously, work has been carried out on finding models of an international form of English, often referred to as English as a Lingua Franca (ELF) (cf. McArthur 2003, 2004, Erling 2005). ELF, however, presents a problem for teaching in so far as it defies any real form of codification. The criteria as to when a variety becomes a variety has been the subject of debate and in terms of ELF in Europe and thus Germany, for example, it is debatable as to whether it can be defined as a variety in its own right. Although Crystal (cf. 1997) envisages a codified and standardised form of ELF akin to his idea of "World Standard English", in reality any descriptive work within this field is in its early stages. As a consequence, in his review of Seidlhofer's contribution in Rubdy and Saraceni (2006), Maley poses a reasonable question when he says "The chapter left me the questions as to the validity of a distinction between ELF ('by definition no one speaks ELF natively' (p.42)), and any variety of English, and left me wondering what precisely the point of ELF is, other than a linguistic research project, if it is not to provide some kind of pedagogic guidance" (2008: 207).

It is precisely in teaching, though, that the value of ELF can be seen. It makes clear that this is quite a separate discussion to ESL i. e. English as Second Language. In essence, ESL and ELF need to be distinguished by the fact that in ESL students use the NS as a fixed point whereas in the ELF context the NS is required to adapt to an international dialogue as statistically speaking the majority of conversations will be held between NNS (Non-Native Speakers). ELF questions the very notion of normative teaching in contexts where NS norms may be seen as a hindrance as opposed to an aid.

Seidlhofer (2001) states that what has arisen is a "conceptual gap" in so far as the ideas, values, ideology and linguistic beliefs of the teacher may be very different to that of the student. Jenkins (2003: 63) points out that aspects of identity, culture and creativity of the student are completely undermined, while Modiano claims that "[...] Instead of verbalizing ideological distinctions verbatim, for example, the establishment and the promotion of ideology is often realized through the inferred acceptance of supposed givens, an activity which inadvertently (or blatantly) impresses upon others a definition of the world" (2001: 163). He continues by 
saying that ideology is implanted into the learners' minds, like soldiers in a Trojan Horse (cf. Modiano 2001: 164).

\section{$4 \quad$ Language and Sprachpraxis}

However, in Sprachpraxis there has been little or no change. The NS model of teaching is still seen as desirable and there has been little or no deviation, in spite of the fact that the questions mentioned have had effects on the teaching of the Sprachpraxis stalwarts such as pronunciation (cf. Petek 2003, Jenkins 2005, Coupland/Bishop 2007) and grammar (cf. Seidlhofer 2001, Ellis 2006). In both areas the underlying question is whether it is appropriate to have students follow an NS model, for example RP pronunciation, and prescriptive grammar or whether students should develop their own sets of written and spoken skills. Ellis (2006: 82f.), for example, emphasises a more contextual teaching of grammar based on factors such as situation, proficiency and the problem areas encountered rather than teaching the whole of grammar. For one, are students of English to be treated as learners of English or users of English and thus to what extent is it even possible to speak of a German style or variety of English? Following on from this, how is grammar then to be taught?

A straightforward case is a mistranslation of Seitdem seine Mutter ihm einen Rechner gekauft hat, hat er sein Zimmer nicht mehr verlassen (my sentence) as Since his mother has bought him a computer he has not left his room instead of Since his mother bought him a computer he has not left his room. The overuse of the present perfect in this case impedes meaning as the temporal clause has been transformed into a clause of reason. Here there is clear-cut case to suggest that this is a grammatical error for the reason mentioned. However, Erling cites other interesting examples that are typical of undergraduate mistakes such as I learn English since ten years (2002: 8) or The story was touching me deeply (ibid.). Aspect is notoriously difficult for German learners of English, as a similar grammatical feature does not exist in the German language. The question as to the correctness is somewhat more difficult to answer as in both cases the meaning of the sentences is not necessarily impeded. Is it a mistake in the traditional NS normative sense, is it stylistically inappropriate or does it indicate the emergence of a German variety of English, which at some point in the future will be accepted on a par with other Englishes?

\section{$5 \quad$ Culture and Sprachpraxis}

Moving away from the purely language aspects of teaching, another area of debate is the role of culture in Sprachpraxis. Culture has, indeed, always played a role in Sprachpraxis, as it was the role of the Lektor to teach students of English the "real" and "genuine" Anglophone culture. As mentioned, the courses were usually referred to as Landeskunde. However, it is certainly questionable whether this form of teaching culture is still appropriate. For a start, as Sommer (2007: 172) mentions, culture in English Studies was until very recently associated with the "traditional literary canon" (ibid.) and Standard English. However, within the university programmes this has expanded to include a plethora of concepts such as gender, postcoloniality, national identity, interculturality and ethnicity (ibid.). From another point of view, many students see language learning as a mode to engage in intercultural communication as opposed to communicating with an NS, according to Erling, as previously mentioned. For one, the chances of a German graduate using English in a purely NNS-NS situation are slim and the chances higher that communication will probably primarily take place within a NNSNNS context.

Although ELF is often characterised as a de-culturalised form of English (cf. Meierkord 2002), the people who use ELF will always be embedded within their own culture (cf. Guillen-Nieto 2005: 10). It has been claimed that cultural interference has indeed caused problems in communication and in this regard, intercultural and cross-cultural communication 
has developed into a subject of research in its own right. Hofstede defines cultural dimensions as "an aspect of culture that can be measured relative to other cultures." (1991: 13). Even though the research by Hofstede concentrates purely on a business context, the dimensions can be applied to Sprachpraxis as intercultural competence is often cited as one of the softskills learned in a degree course in English, as mentioned in Diploma Supplements. On a more practical level, intercultural teaching can also be helpful with regard to style or argumentation strategies for example. House (2006) states that while very often the psychological dimensions are concentrated on, in fact these dimensions have linguistic consequences. In student writing problems appear not necessarily always due to an incorrect use of grammar and vocabulary but is often deemed as stylistically clumsy due to the fact they have attempted to transfer a German style of argumentation onto English. House (ibid.: 252), who is in fact referring to taped conversations, lists different cultural dimensions such as directness as opposed to indirectness or focus on content as opposed to focus on audience, but is quick to point out that she is referring to tendencies and not dichotomies. This is certainly an area of research and work that could fall into the Sprachpraxis domain. While it is not being suggested that German students should simply adopt an NS style of writing but a critical reflection on these differences and more importantly on the linguistic manifestations would certainly not harm a student and the development of their linguistic identity. Secondly, many students of English have the desire to spend a semester or even pursue an M.A. abroad and certainly this awareness can be advantageous.

\section{Sprachpraxis and English for Academic Purposes}

Thus, if the language aspect of Sprachpraxis i. e. NS adherence, has seriously been questioned and culture can no longer be defined in its original Landeskunde form, then what in fact is left for a Lektor to actually teach? One of the major features of ELF mentioned by Meierkord and Knapp (2002: 10) is the use of language in specific contexts. Kress (1989), cited by Hyland states that genres are "the effects of the action of individual social agents acting both within the bounds of their history and the constraints of particular contexts, and with a knowledge of existing generic types." (Hyland 2002: 114). This has led to the rise within the English teaching industry of English for Special Purposes (ESP). As far back as 1983, Carter identified three types of ESP, the first being English as a restricted language for example in air-traffic control. Secondly, English for Academic or Occupational Purposes and finally English with specific topics such the medical field. (cf. Gatehouse 2002: 4). This view is echoed by Dudley-Evans and St. John (1998: 72), who cite the example of comparing English for Academic Purposes and English for Business Purposes. The former relates to the continual development of the individual to interact within a given field, whereas the latter is primarily concerned with a situational context and the transaction is the primary focus as opposed to the individual.

However, the more ESP focussed the class is to be the more an inherent contradiction arises. For an ESP course to fulfil the criteria set out by Dudley-Evans and St. John, more research is required to tailor the course content to the students (cf. Gatehouse 2001: 8). She (ibid.) quotes Johns to answer the question as to whether an ESP course book can even exist. Johns states "ESP teachers find themselves in a situation where they are expected to produce a course that exactly matches the needs of a group of learners, but are expected to do so with no, or very limited, preparation time" (Johns 1990: 91), a view reiterated by Swales (2000: 62), who points out that ESP has what he calls "a long tail" in so far as there are very few research positions in this field, which is comprised of primarily part-time teachers.

\section{$7 \quad$ Sprachpraxis and Mass customization}

It is within these contexts that "Sprachpraxis" and mass customization has to be addressed. When looking at the various and multifarious influences and questions it becomes quite clear 
why the traditional and sometimes unreflected adherence to NS norms and thus teaching English in this monolithic form can no longer be seen as desirable. A number of points in relation to Sprachpraxis need further investigation. Firstly, to what degree is Sprachpraxis the teaching of General English as a reflection of NS use or has it in fact developed into a form of ESP? If so, what justification is there for keeping Sprachpraxis within the domain of a degree in English and not simply outsourcing the teaching to a university language centre, a fear mentioned by Schlaeger (2007: 231). If that is the case, to which degree is the teaching a form of EAP? In contrast to disciplines such as medicine, biology etc. the goal in Sprachpraxis should be to aid a development in an occupational domain, as mentioned by Carter. Taking this further, if the argument is such that "Sprachpraxis" is a form of EAP, then to what end? Which discipline does it seek to serve or which specific form of EAP within English Departments is being referred to and is desired? To summarize, how specific is the teaching to be, as Gnutzmann points out "The general language provides the basis for LSP terminology in the humanities and social sciences." (2009: 519).

The fact that the students are in an academic context and written academic English as opposed to spoken English is more conservative and lexico-grammatical accuracy of paramount importance, the focus could move away from teaching prescriptive grammar in a black-andwhite right and wrong sense to perhaps placing the focus on style and register within academic conventions. Taking this point further, whether there is a role for translation courses in this context? There is certainly a case to be made using translation as a teaching tool. Cook claims that translation should be made one of the core elements of teaching and initially cites three reasons: "cognitively, as an aid to language acquisition; pedagogically, as a motivating factor; and functionally, as a needed skill." (2007: 398) His fourth and most important reason is that translation preserves the identity of the speaker: "Many contemporary learners do not learn English to become monolingual speakers, but rather to create a bilingual identity. [...] In these circumstances, translation seems both useful and right." (2007: 399). Conversely, there are as many reasons that would suggest a monolingual approach is more beneficial to the students. Thus, is the goal of translation merely to teach translation or to highlight problem areas and and is it simply better to concentrate on production skills and deal with problems as they arise?

The intention here is not to deconstruct everything that has gone before. However, what is being suggested is that perhaps mass customization is the key for the future. In spite of the fact that there is a high level of scepticism towards Bologna and the introduction of the B.A./M.A. system in Germany, certain aspects of the system, such as modularisation, can in fact be of benefit to Sprachpraxis. Much of the debate that has been discussed so far is based on opposites in a sense of what to teach and what not to teach, but why not give the students the options? Why not give the students the choice which line of teaching and learning they prefer? This can apply to the traditional grammar and translation classes. If certain students feel that what they need is a formal solid grounding in these disciplines they should have the option to do so. Others, meanwhile, may feel that they are better served practicing the production of language in for example writing and oral presentation classes. Some students may feel early on that an academic career is not for them while, again, others may see that as their calling. There is no doubt that a certain common ground is needed in so far as every student of English will need to produce a B.A. dissertation in English and certainly the written skills to do so need to be trained, but for those who seek to pursue an academic career, the mass customization would allow for special tutelage as opposed to more generic English classes. This can manifest itself on a micro-level. For a start, academic writing entails a high number of grammatical structures such as passives and nominalisations (cf. Gnutzmann 2009: 528) and traditional grammar classes could thus be adapted to suit this particular need, reflecting Ellis' point on the usefulness of teaching the whole grammar. The same applies to culture as the intercultural dimensions within an academic context could be introduced simultaneously. 
On the other hand, while culture and its teaching has of course changed, as mentioned, there is still a place for "authentic" Anglophone culture or Landeskunde as part of a degree in English. It should be left up to the students as to whether they would like to pursue this. A last line of choice could also be for students who seek a career as a schoolteacher. Perhaps it would be more useful to teach these students the didactics of the English language as opposed to translation courses, Landeskunde or even EAP.

However, for such a system to be put in place a certain number of provisos would need to be met in a number of areas. Firstly, on an institutional level, a teaching and examining system would need to be put in place that allows for this eclectic approach. Moreover, universities would need to invest in Sprachpraxis but the advantages would be manifold. On a teachinglevel, the more classes there are on offer the smaller the student numbers would be. At present Sprachpraxis classes of eighty or more students are not uncommon in German universities. In addition, funding would give Lektoren time to pursue research interests outside of the classroom. This in turn would lay the groundwork for Sprachpraxis to become established as a discipline in its own right and for the research to be directly applied to the teaching within the given institution.

Secondly, it requires students to re-think their approach to English. Sprachpraxis is presently defined by a prescriptive approach to language and students are literally told what to do. However, a modularised system of teaching Sprachpraxis would place the students in a situation in which they would have to take responsibility and reflect on their abilities and their interests. There is of course the inherent risk of students taking "the path of least resistance" but ultimately this should be their choice. It would also give the students more "Praxis" and in addition, more autonomy. Of course Lektoren can be guides. If a Lektor sees that certain students have severe difficulties in expressing themselves then perhaps a more basic grammar or translation course might be of more use to them instead of for example a Landeskunde or EAP course. This approach in turn is directly applicable to the problem of differing proficiency levels among students of English. More importantly it would give the students the freedom to develop their own linguistic identities, which is one of the main arguments in the debate on pedagogy. If this identity and the desired goal is near-native competence, then the student should be given the opportunity to follow it. Not only does it allow students to look at their needs it also provides a basis for the students to think about where or how they may want to use English in the future.

Most importantly, the definition of a Lektor would need to be adapted. For a start, a Lektor need not be a NS. One of the main consequences of the global debate is that the notion of the Native Speaker as the only true instructor has been questioned for example by Brutt-Griffler and Saminy (2001), who claim that the NS is a social as opposed to a linguistic construct, a point reiterated by Dostert, who states "A native speaker of the language L is someone who has learnt L naturally from their environment (normally their parents) from birth or very early childhood i.e. for whom $\mathrm{L}$ is the first language (or in the case of child bilingualism, one of two or more first languages) and who was exposed to and brought up with L for the first (roughly 14-16) years of life." (2010: 198). The NS is defined by their heritage as opposed to their linguistic abilities. However, it is individuals and not groups that teach classes and yet within Sprachpraxis there is still an almost unquestioned adherence to NS teachers, even though they may not be most suitable or qualified people to teach. In fields such as translation for example the English departments might be better served employing a Lektor with a German language background. If the focus is on EAP, a Lektor with experience in publishing academic articles might be of more benefit to the students. Finally, if a student were interested in Landeskunde, then an NS Lektor from the country in question would be most appropriate. This model also requires Lektoren to fulfil other functions. A system of specialisation requires the Lektoren to pursue research in their fields. What has developed is a chasm between the 
applied linguistic debate and the language teaching as a whole. In essence, it can be summarised as the difference between "technical knowledge" and "practical knowledge" (cf. Ellis 2001: 46f.) Technical knowledge is explicit and codifiable. Ellis refers to the debate on SLA and its relevance in the classroom. On the other hand, practical knowledge is implicit and is the result of many years of trial and error within the classroom context. Ellis (cf. 2001: 60ff.) argues that these strands need not be mutually exclusive. However, it calls for a re-appraisal on both sides. On the one hand, Lektoren need to break out of the tried and tested routines and be more willing to engage in innovative practices within the context of the course itself. Factors such as feasibility and applicability are vital in this regard. The applied linguistic debate needs to take precisely these considerations into account. It would be conversely advantageous for the Lektoren to take the applied linguistic debate on board. Areas such as corpus linguistics will play an increasingly significant role in teaching (cf. Krishnamurthy/Kozem 2007). Examples of this are I.C.L.E. (cf. Granger 2003), V.O.I.C.E. (cf. Seidlhofer 2001), L.F.C. (cf. Jenkins 2002) and more specifically in the academic context E.L.F.A. (cf. Mauranen 2003) or C.H.A.L.K (cf. Römer 2009) to name but a few. There is no cogent reason why this cannot be applied to Sprachpraxis. Through the development of corpora a more realistic picture of the students i. e. their skills and needs can be established. The problem of researching purely within a classroom context is that it leads to a top-down approach, as the classroom is a rather prescriptive environment in the first place. In addition, other areas of inquiry for Lektoren could be to increase their knowledge of the other disciplines within the English departments they serve. It would certainly be advantageous for the students who have chosen an academic path to have Lektoren who themselves have a level of knowledge of the fields in question. As such, what is required of Lektoren is to become aware of the major debates taking place in Literary Studies, Linguistics and Medieval Studies. A positive sideeffect of this would be that it sets Sprachpraxis apart from courses offered by language institutes, which may in effect allay some of the fears mentioned by Schlaeger. It is by no means being suggested that language institutes are of lesser value, it is more that the teaching staff have different specialisations.

\section{Conclusion}

There are many arguments as to why Sprachpraxis and primarily the students of English could benefit from mass customization. However, it will always be a question of feasibility. Sprachpraxis, like any number of actual departments across the board in various disciplines, is a subject to a lack of funding. There is little likelihood of this changing in the near future. As mentioned, to give the students this level of choice would require a huge increase in spending and many more full-time positions. The average tenure of a Lektor is two years. It is highly unlikely that Lektoren in these positions will have either the time or the interest to pursue research projects that may be used directly in the classroom in a given institution. Even if research projects were undertaken and tangible results introduced, any change still must go through a (re-) accreditation process and therefore an ad hoc introduction in the curriculum is impossible. The object here is not to question institutional policy or the work being carried out by Lektoren at present. Indeed, as is the case in any position in any university, one has to confront institutional and personal constraints. In addition, this is not to be seen as a comprehensive overview of the issues involved. Were in fact a system of mass customization introduced, factors such as methodology, curricular design, examination strategies or use of media would need to be discussed in detail. The contribution here is designed more as a set of hypothetical questions that could be asked and lines of inquiry that could be looked into. It is, as is so often the case in life, a question of theory and practice. 


\section{References}

Brutt-Griffler, Janina/Keiko, Samimy (2001): "Transcending the Nativeness Paradigm". World Englishes 20/1: 99-106.

Cook, Guy (2007): "A Thing of the Future: Translation in Language Learning". International Journal of Applied Linguistics 17/3: 396-401.

Coupland, Nicholas/Bishop, Hywel (2007): "Ideologised values for British accents". Journal of Sociolinguistics 11/1: 74-93.

Crystal, David (1997): English as a Global Language. Cambridge: Cambridge University Press.

Dostert, Susan (2010): Multilingualism, L1 Attrition and the Concept of 'Native Speaker'. PhD Thesis, Heinrich-Heine Universität, Düsseldorf. http://docserv.uniduesseldorf.de/servlets/DocumentServlet?id=15440, accessed October 7, 2010.

Dudley-Evans, Tony/St. John, Maggie Jo (1998): Developments in ESP: a multi-disciplinary approach. Cambridge: Cambridge University Press.

Ellis, Rod (2001): "Second Language Acquisition: Research and Language Pedagogy". In: Candlin, Christopher N./Merver, Neil (eds.): English Language Teaching and its Social Context. Oxford, Routledge: 44-74.

Ellis, Rod (2006): "Current Issues in the Teaching of Grammar: an SLA perspective". TESOL Quarterly 40/1: 83-107.

Erling, Elizabeth J. (2002): "'I learn English since ten years': The global debate and the German University Classroom". English Today 18/2: 8-13.

Erling, Elizabeth J. (2004): Globalisation, English and the German University Classroom: A Sociolinguistic Profile of Students of English at the Freie Universität Berlin. PhD Thesis, University of Edinburgh. http://userpage.fu-berlin.de/ berling/Final\%20Draft\%20pdf.pdf, accessed September 18, 2007.

Erling, Elizabeth J. (2005): "The many names of English". English Today 81: 40-44.

Gatehouse, Kristen (2001): "Key issues in English for Specific Purposes (ESP) Curriculum development". The Internet TESL Journal: 1-10.

Gnutzmann, Claus (2009): "Language for Specific Purposes vs. General Language". In: Knapp, Karlfried/Seidlhofer, Barbara/Widdowson, Henry (eds.): Handbook of Foreign Language Communication and Learning. Berlin/New York, Mouton de Gruyter: 517-544.

Granger, Sylviane (2003): "The International Corpus of Learner English: a new resource for foreign language learning and teaching and second language acquisition research". TESOL Quarterly 37/3: 538-546.

Guillén Nieto, Victoria (2005): „The invisible face of culture: Why do Spanish toy manufacturers believe the British are most peculiar in business?". In: Mateo Martínez, José/Yus, Francisco (eds.): Thistles. Alicante, Departamento de Filología Inglesa, Universidad de Alicante: 96-127. http://rua.ua.es/dspace/bitstream/10045/4184/2/The invisible face of culture.pdf, accessed August 14, 2009.

Hofstede, Geert (1991): Cultures and Organizations. London: Profile Books.

House, Juliane (2006): "Communicative styles in English and German". European Journal of English Studies 10/3: 249-267.

Hyland, Ken (2002): "Genre: Language, Context and Literacy". Annual Review of Applied Linguistics 22: 113-135.

Jenkins, Jennifer (2002): "A sociolinguistically based, empirically researched pronunciation syllabus for English as an International Language". Applied Linguistics 23/1: 83-103.

Jenkins, Jennifer (2003): World Englishes: A resource book for students. London: Routledge.

Jennifer, Jenkins (2005): "Teaching Pronunciation for English as a Lingua Franca: a sociopolitical perspective". In: Gnutzmann, Claus/Frauke Intemann (eds.): The Globalisation of English and the English Language Classroom. Tübingen, Narr: 145-158. 
Kayman, Martin A./Locatelli, Angela/Nünning, Ansgar (2006): "Editorial: On being 'European' in English". European Journal of English Studies 10/1: 1-12.

Krishnamurthy, Ramesh/Kosem, Iztok (2007): "Issues in creating a Corpus for EAP Pedagogy and Research". Journal of English for Academic Purposes 6: 356-373.

Maley, Alan (2008): "Review: Kirkpatrick, Andy (2007) 'World Englishes: Implications for international communication and English language teaching' Cambridge: Cambridge University Press \& Rubdy, R. \& M. Saraceni (eds.) (2006) 'English in the world' London: Continuum". ELT Journal 62/2: 205-209.

Mauranen, Anna (2003): "The Corpus of English as Lingua Franca in Academic Settings". TESOL Quarterly 37/3: 513-527.

McArthur, Tom (2003): "World English, Euro-English, Nordic English". English Today 19/1: $54-58$.

McArthur, Tom (2004): "Is it World or International or Global English and does it matter?". English Today 20/3: 3-15.

Meierkord, Christiane (2002): "'Language stripped bare' or 'linguistic masala'? Culture in Lingua Franca Conversation". In: Knapp, Karlfried/Meierkord, Christiane (eds.): Lingua Franca Communication. Frankfurt/Main, Lang: 109-133.

Meierkord, Christine/Karlfried Knapp (2002): "Approaching Lingua Franca Communication". In: Knapp, Karlfried/Meierkord, Christiane (eds.): Lingua Franca Communication. Frankfurt/Main, Lang: 9-28.

Modiano, Marko (2001): "Ideology and the ELT practitioner". International Journal of Applied Linguistics 11/2: 159-173.

Petek, Klementina Jurancic (2003): "Is it enough to teach segments in (segmental) phonetics and phonology?". In: Ketteman, Bernd/Georg Marko (eds.): Expanding circles, Transcending Disciplines, and Multimodal Texts. Tübingen, Narr: 59-68.

Römer, Ute (2009): "English in Academia: Does Nativeness matter?". Anglistik: International Journal of English Studies 20/2: 89-100.

Schlaeger, Jürgen (2007): "The Future of English Studies in Europe". In: Nünning, Ansgar/Schlaeger, Jürgen (eds.): English Studies Today: Recent Developments and New Directions. Trier, WVT Wissenschaftlischer Verlag Trier: 223-239.

Seidlhofer, Barbara (2001): "Closing a Conceptual Gap: the case for a description of English as a Lingua Franca". International Journal of Applied Linguistics 11/2: 133-158.

Seidlhofer, Barbara (2006): "English as a Lingua Franca in the Expanding Circle: what it isn't". In: Rubdy, Rani/Saraceni, Mario (eds.): English in the world. London, Continuum: $40-50$.

Sommer, Roy (2007): "From Cultural Studies to the Study of Culture: Key Concepts and Methods". In: Nünning, Ansgar/Schlaeger, Jürgen (eds.): English Studies Today: Recent Developments and New Directions. Trier, WVT Wissenschaftlischer Verlag Trier: 165191.

Swales, John M. (2000): "Language for Specific Purposes". Annual Review of Applied Linguistics 20: 59-76. 